\title{
Atlantic salmon (Salmo salar) postsmolts adapt lipid digestion according to elevated dietary wax esters from Calanus finmarchicus
}

\author{
A.S. BOGEVIK ${ }^{1,5}$ *, D.R. TOCHER ${ }^{2}$, E. LANGMYHR ${ }^{3}$, R. WAAGB $\emptyset^{4,5}$ \& R.E. OLSEN $^{1}$ \\ ${ }^{1}$ Institute of Marine Research, Matre Aquaculture Research Station, N-5984 Matredal; ${ }^{2}$ Institute of Aquaculture, \\ University of Stirling, Stirling, Scotland FK9 4LA, UK; ${ }^{3}$ Norwegian Institute of Fisheries and Aquaculture \\ Research, Fyllingsdalen, Norway; ${ }^{4}$ National Institute of Nutrition and Seafood Research (NIFES), Bergen, Norway; \\ ${ }^{5}$ Department of Biology University of Bergen, Bergen, Norway
}

*Correspondence: André S. Bogevik: Institute of Marine Research, Matre Aquaculture Research Station, N-5984 Matredal.Email:andreb@imr.no; Tel: +47-56367535; Fax:+47-56367585

Keywords: Wax esters, salmon, growth, digestion, bile, bile-salt dependent lipase 


\begin{abstract}
Wax esters in copepods constitute huge natural marine lipid resources, which can contribute as future lipid source in formulated diets in aquaculture, and thereby reduce the pressure on use of marine resources at higher trophic levels. The present study was undertaken to investigate factors affecting wax ester digestibility, including production of bile and lipases, in Atlantic salmon fed diets containing high proportions of an oil derived from copepods. Individually tagged postsmolt Atlantic salmon (initial weight $250 \mathrm{~g}$ ) were distributed into three dietary groups in triplicate tanks and fed either a fish oil supplemented diet, or diets where $50 \%$ or $100 \%$ of the fish oil was replaced with oil extracted from Calanus finmarchicus. Wax esters accounted for 307 or $477 \mathrm{~g}$ $\mathrm{kg}^{-1}$ of the lipids in these latter diets, respectively. Over the 100 day feeding period, the salmon fed the fish oil diet displayed a significantly higher specific growth rate (SGR; 0.74) than fish fed the $100 \%$ Calanus oil diet (SGR; 0.67). The apparent digestibility coefficient of total lipid and total fatty acids was significantly higher in salmon fed the fish oil and the mixed diet than in fish fed the pure Calanus oil diet. However, the fish appeared to adjust lipid digestibility to the increased intake of wax ester by enhancing bile volume and the lipolytic activity. The study indicates that Atlantic salmon show adaptations in digestion to elevated dietary wax ester intakes, however with an upper limit for optimal utilization in practical diets.
\end{abstract}

\title{
Introduction
}

If the carnivorous aquaculture industry continues to grow as it has during the past decade, there will be a shortage of marine oils with valuable n-3 highly unsaturated fatty acids (n-3 HUFA) within a few years (FAO 2006). As n-3 HUFA are only found in large quantities in the marine environment, it is essential to find alternative unexploited marine oil resources. One such alternative is to sustainably harvest from lower trophic levels. The biomass of krill and copepods 
is huge, and the annual production in the waters off Norway is in the magnitude of several hundred million tonnes (Dalpadado et al. 1998; Madden et al. 1999). A harvest of a few million tonnes could cover the feed requirements for fish farming in foreseeable future, arguably without impacting the marine ecology. While some species of krill have low lipid content (e.g. Meganyctiphanes norvegica, Euphausia superba) and represent mainly feed protein sources, other species like Thysanoessa inermis and calanoid copepods have high levels of storage lipid during parts of the season (Kattner \& Krause 1987; Sætre \& Mohr 1987; Falk-Petersen et al. 2000). However, many of these organisms, and a few other marine invertebrates and mesopelagic fish species, have wax esters (WE) as their main lipid storage component rather than triacylglycerols (TAG), the main storage lipid in most fish species (Sargent et al. 1976; FalkPetersen et al. 1982).

TAG consists of three fatty acids esterifies to glycerol, whereas WE consists of one fatty acid esterified to a long-chain fatty alcohol. These esters are generally considered to be less accessible and poorly digestible than TAG in mammals (Place 1992). Many fish, including juvenile Atlantic salmon, Salmo salar L. are however known to feed on copepods and krill species containing substantial amounts of WE (Rikardsen et al. 2004). It is therefore expected that the capacity to utilize these lipids should be well developed in marine fish. However, current knowledge is relatively limited with regard to this ability. Past studies have shown that WE are hydrolyzed, and that the fatty alcohols are absorbed, oxidized to fatty acids, and incorporated into TAG in several fish species (Patton \& Benson 1975; Bauermeister \& Sargent 1979). However, the reported rate of hydrolysis appears to be much slower than for TAG (Patton et al. 1975). A lower utilization was previously reported in rainbow trout, Oncorhynchus mykiss L. although the fish also appeared capable of increasing the bile volume in response to feeding diets with elevated WE (Tocher \& Sargent 1984). Recently, Olsen et al. (2004), showed that Atlantic salmon fed a diet 
containing $260 \mathrm{~g} \mathrm{~kg}^{-1}$ lipid of which $375 \mathrm{~g} \mathrm{~kg}^{-1}$ was WE had similar growth and feed conversion efficiency as fish maintained on a diet containing only fish oil, suggesting a complete adjustment to the WE-rich diet. These data lead us to a hypothesize that the hydrolysis of WE is lower than for TAG, but that Atlantic salmon are capable of adapting digestive capacity to maintain a high level of lipid utilization.

In order to test this hypothesis, the current study was designed to evaluate the effect of replacing fish oil with increasing level of WE in a standard diet on growth rate, nutrient digestibility, bile composition and midgut lipolytic activity in Atlantic salmon smolts.

\section{Material and methods}

\section{Diet preparation}

Lipid extraction from Calanus and feed preparations were performed at the experimental plant of The Norwegian Institute of Fisheries and Aquaculture at Fyllingsdalen (Bergen, Norway). $C$. finmarchicus were purchased block frozen from Norsk Medicinal Union (Bergen, Norway). Calanus was heated to $85-90{ }^{\circ} \mathrm{C}$ in a scraped surface heat exchanger (Contherm $4 \times 6$, Alfa Laval, Rødovre, Denmark), and most of the liquid phase removed in a double screw press (P13, Stord Bartz, Bergen, Norway). The press liquid was then heated to above $90{ }^{\circ} \mathrm{C}$ for 10 minutes in a steam-heated vessel, and particulate matter was removed using a rotary sieve (Jesma vs 20/65, H. Jessens Maskinbyggeri, Vejle) with $100 \mu \mathrm{m}$ screen. The purified oil was separated in an oil separator (SA1, Westfalia Separator AG, Oelde, Germany) . A low fat basal pellet was prepared by extrusion using similar standards and additives as in commercial diets. The pellets were then vacuum coated with fish oil (control diet), fish oil/Calanus oil (1:1 v/v; mixed diet) or Calanus oil (Calanus diet) to a total fat level of $30 \%$ (table 1). All diets contained $0.01 \%$ yttrium oxide as 
digestibility marker.

Fish

One hundred and eighty 11 months old, vaccinated, postsmolt Atlantic salmon, Salmo salar L. (NLA strain; AquaGen Norwegian salmon breeding programme), of average weight $250 \pm 30 \mathrm{~g}$ were anaesthetized in benzocaine $\left(4 \mathrm{~g} \mathrm{~L}^{-1}\right)$ and measured for length (to nearest $0.1 \mathrm{~cm}$ ) and weight (to nearest $1 \mathrm{~g}$ ) before being individually tagged with a passive induced transponder (Trovan pit tag, ID100, Stavanger, Norway). The fish were then transferred into nine $1.5 \times 1.5 \times 1$ $\mathrm{m}^{3}$ standard fibreglass tanks equipped with waste feed collectors. The fish were supplied with aerated seawater $\left(9.6 \pm 0.9{ }^{\circ} \mathrm{C}\right)$ and kept under constant light regime at the Institute of Marine Research, Matre Aquaculture Research Station (Matre, Norway). The three diets were fed to triplicate tanks every day using disc feeders, during two hours every morning and afternoon.

Most parameters were measured after feeding the experimental diets for 100 days. At that time, fish were anaesthetized in benzocaine, measured for length and weight, and faeces stripped from all fish. The faeces samples from each tank were pooled and stored at $-80^{\circ} \mathrm{C}$ prior to analysis of digestibility parameters (dry matter, total lipid, total protein, total fatty acids, total fatty alcohols and yttrium). The fish were then returned to their respective tanks where they continued to be fed for another 36 days. Then, 10-12 hours after the last feeding, five fish from each tank were collected by random, anaesthetized by use of benzocaine bath and killed by a sharp blow to the head. The luminal contents of the intestine were collected from the midgut region, defined as the area from the last pyloric caeca to the start of the distal intestine, as recognised by its larger diameter, for the analysis of lipolytic enzyme activities (Olsen et al. 1999). The remaining fish were starved for $72 \mathrm{~h}$, anaesthetized and killed as above, and bile collected from the gall-bladder 
with a $5 \mathrm{ml}$ syringe with $0.1 \mathrm{ml}$ resolution. After recording the volume, the bile was stored at -80 ${ }^{\circ} \mathrm{C}$ for analysis of bile salts and bile composition, specifically dry matter, total protein, phospholipids content and osmolality.

\section{Gross chemical composition of diet and faeces}

Diets and portions of stripped faeces were heated at $105{ }^{\circ} \mathrm{C}$ for $24 \mathrm{~h}$ to obtain dry weight, followed by analysis of yttrium oxide according to Otterå et al. (2003). Diet protein was analysed by a combustion method as total $\mathrm{N}$ (protein $=$ total nitrogen $\mathrm{x} 6.25$ ) by use of a Leco FP-528 Nanalyser and Leco software (Leco Corporation, St. Joseph, MI, USA) according to AOAC (1995). Faeces were extracted in to 5-fold of $0.1 \mathrm{M} \mathrm{HCl}$ and further diluted 20-fold with Tris/HCl buffer (0.2 M, pH 8.4), before protein content was assessed by the method of Lowry et al. (1951) using a spectrophotometer (Ultrospec 4000; Pharmacia Biotech, Cambridge, England) set at 750 nm.

Total lipid of diets and faeces was extracted with chloroform/methanol $(2: 1 \mathrm{v} / \mathrm{v})$ according to Folch et al. (1957). Dilute $\mathrm{HCl}$ (3 M, 30\% of original faeces weight) was added to the resulting faecal pellet before the last extraction, to dissolve any calcium soaps present. After evaporation to dryness in vacuo at room temperature, total lipid was re-dissolved in chloroform/methanol (2:1 $\mathrm{v} / \mathrm{v}$ ) and stored under nitrogen at $-80{ }^{\circ} \mathrm{C}$ prior to analysis.

Yttrium was determined in feed and faeces by use of an ICP-MS (inductive-coupled plasma mass spectrometry) method after wet digestion in a microwave oven (Otterå et al 2003).

Lipid class composition of total lipid was determined by one-dimensional double-development 
high-performance thin layer chromatography (HPTLC) coupled with scanning densitometry, as described by Olsen and Henderson (1989). Methyl acetate/isopropanol/chloroform/ methanol/ $/ 2.25 \%$ aqueous $\mathrm{KCl}(25: 25: 25: 10: 9 \mathrm{v} / \mathrm{v})$ was employed as the first developing solvent and isohexane/diethyl ether/glacial acetic acid $(85: 15: 1 \mathrm{v} / \mathrm{v})$ as the second solvent. The stained plates were scanned using a Camag 3 TLC Scanner (Camag, Muttenz, Switzerland) and winCATS software. The identities of individual lipid classes were confirmed by comparison with reference to the Rf value of authentic standards run alongside samples on HPTLC plates and developed in the above solvent systems.

\section{Digestibility of fatty acids and fatty alcohols}

Total lipid of diets and faeces were subjected to acid-catalyzed transesterification using $1 \%(\mathrm{v} / \mathrm{v})$ $\mathrm{H}_{2} \mathrm{SO}_{4}$ in methanol (Palmquist \& Jenkins 2003) with 17:0 fatty acid and fatty alcohol as internal standards. The resulting fatty acid methyl esters (FAME) were extracted and purified using thin layer chromatography (TLC) on $20 \times 20 \mathrm{~cm}$ TLC plates as described previously (Tocher \& Harvie 1988). The long-chain alcohols present in the lipid samples from faeces of fish fed the Calanus oil diet were identified on the TLC plates as a single component and recovered from the adsorbent by elution with chloroform/methanol $(2: 1 \mathrm{v} / \mathrm{v})$. The total fatty alcohols were then subjected to acetylation according to the acetic anhydride/pyridine procedure as described by Farquhar (1962). The fatty alcohol acetates were purified on TLC as described above for FAME.

FAME and long-chain alcohols acetates were separated and quantified by gas liquid chromatography using a $30 \mathrm{~m} \times 0.32 \mathrm{~mm}$ i.d. fused silica capillary column coated with ZB-Wax (Phenomenex, Macclesfield, UK) and a Thermo Finnigan Trace gas chromatograph. Hydrogen was used as carrier gas and temperature programming was from 50 to $150{ }^{\circ} \mathrm{C}$ at a rate of $40{ }^{\circ} \mathrm{C}$ 
$\min ^{-1}$, from 150 to $195{ }^{\circ} \mathrm{C}$ at $1.5^{\circ} \mathrm{C} \min ^{-1}$, and then to a final temperature of $205{ }^{\circ} \mathrm{C}$ at $0.5^{\circ} \mathrm{C}$ $\min ^{-1}$. Individual components were identified by comparison with known standards. The absolute amounts of individual fatty acids and long-chain alcohols present were calculated by reference to the internal standard (Olsen et al., 2004).

\section{Bile analysis}

Analysis of conjugated bile salts was performed essentially according to Coca et al. (1994). In brief, $5 \mu \mathrm{l}$ of internal standard (dexamethasone; $20 \mathrm{mg} \mathrm{ml}^{-1}$ ) was added to $100 \mu \mathrm{l}$ bile and the mixture diluted 50-fold in $0.7 \mathrm{M}$ phosphate buffer $\mathrm{pH} 7.0$ and vortexed for $1 \mathrm{~min}$. The solution was passed through a $\mathrm{C}_{18}$ Sep-Pak cartridge (Sep-Pak ${ }^{\circledR}$ Vac 6cc; Waters, Milford Massachusetts, USA) previously conditioned with $5 \mathrm{ml}$ methanol, $10 \mathrm{ml}$ water and $5 \mathrm{ml} 0.7 \mathrm{M}$ phosphate buffer pH 7.0. Conjugated bile salts were eluted with $5 \mathrm{ml}$ methanol after a wash of $10 \mathrm{ml}$ water, $3 \mathrm{ml}$ $10 \%$ acetone and $10 \mathrm{ml}$ water, and dried under a stream of nitrogen at $40{ }^{\circ} \mathrm{C}$. The conjugated bile salts were redissolved in the mobile phase, filtered through a $0.2 \mu \mathrm{m}$ syringe filter $\left(\right.$ Nalgene ${ }^{\circledR}$, Nalge Nunc International, Rochester, USA) before $20 \mu \mathrm{l}$ was injected into an Alliance HPLC system consisting of a Waters 2690 Separation Module and a Waters 996 Photodiode Array Detector set at a fixed wavelength of $\lambda=205 \mathrm{~nm}$. The samples were separated on a LiChrospher RP18 Column (250 X 4.6 mm, id $5 \mu \mathrm{m}$ ) (Supelco, Inc., Bellefonte, USA) with methanol/0.5 M acetate buffer $\mathrm{pH} 4.3(70: 30, \mathrm{v} / \mathrm{v})$ as mobile phase and bile salts identified with reference to authentic standards.

Bile protein analyses were performed spectrophotometrically as described above after a 5 times dilution with phosphate buffer (0.7 M, pH 7.0). Bile osmolality was measured using a Fiske one- 
ten osmometer (Fiske Associates, Norwood, Ma, USA) with calibration and reference solutions (290 $\mathrm{mOsm} \mathrm{L}^{-1}$ ) from the manufacturer. Total phospholipid (PL) composition was assessed through phosphorous analysis of lipids from bile, extracted by the method of Folch et al. (1957). Phosphorous was determined after dilution, using an ICP-SFMS method (ALS Analytica, Oslo Norway). A general molecular weight for PL $\left(\mathrm{C}_{46} \mathrm{H}_{88} \mathrm{NO}_{8} \mathrm{P}\right)$ of $814.14 \mathrm{~g} \mathrm{~mol}^{-1}$ (Cohen 1996) was used in the calculations of PL concentration from the phosphorous concentration in bile.

\section{Assay of triacylglycerol, wax ester and sterol ester hydrolase activities}

Unlabelled trioleate, palmityl oleate and cholesteryl oleate were purchased from Sigma-Aldrich, St. Louis, USA. Tri- $\left[1-{ }^{14} \mathrm{C}\right]$ oleate (TAG, $\left.54 \mathrm{mCi} / \mathrm{mmol}\right)$ and cholesteryl $\left[1-{ }^{14} \mathrm{C}\right]$ oleate (SE, 61 $\mathrm{mCi} \mathrm{mmol}^{-1}$ ) were purchased from Amersham Biosciences (Buckinghamshire, UK). Radiolabelled wax esters (palmitoyl $\left[1-{ }^{14} \mathrm{C}\right]$ oleate, WE) were prepared from $\left[1-{ }^{14} \mathrm{C}\right]$ oleic acid $(50$ $\mathrm{mCi} \mathrm{mmol}{ }^{-1}$, ARC, St. Louis, USA) and unlabelled palmitoyl (cetyl) alcohol (Sigma Chemical Co, Poole, UK) using the acid anhydride method of Tocher \& Sargent (1984). All samples were stored in toluene at $-80{ }^{\circ} \mathrm{C}$ prior to use. To prepare lipase substrates, the radiolabelled lipids were diluted with cold substrates to specific activities of $2-5 \mathrm{dpm} \mathrm{pmol}{ }^{-1}$. The solvent was evaporated under a stream of nitrogen and the residue dissolved in warm acetone $\left(50^{\circ} \mathrm{C}\right)$ and injected in small portions into ice-cold 5\% fatty acid-free bovine serum albumin (BSA) solution, containing $10 \mathrm{mM}$ EDTA and 0.1 M phosphate buffer $\mathrm{pH}$ 8.0. The mixture was stirred for $15 \mathrm{~min}$, stored at $4{ }^{\circ} \mathrm{C}$, and stirred for 2-3 min before use. The final concentration of each substrate suspension was $500 \mu \mathrm{M}$ (Tocher \& Sargent 1984).

Luminal contents from the midgut was diluted 4-fold $\left(\mathrm{w} \mathrm{v}^{-1}\right)$ in $0.1 \mathrm{M}$ phosphate buffer, $\mathrm{pH} 8.0$ 
(ambient $\mathrm{pH}$ of the salmon midgut). The suspension was centrifuged at $3220 \mathrm{x} g$ for $10 \mathrm{~min}$ at 4 ${ }^{\circ} \mathrm{C}$ to remove particulate material. To remove endogenous bile salts, the supernatant was then transferred to Zeba ${ }^{\mathrm{TM}}$ Desalt Spin Columns (Pierce, Rockford, USA) and centrifuged at $200 \mathrm{x} g$ for 2 min at $4{ }^{\circ} \mathrm{C}$. The desalted extracts were analysed for protein content as described above and the protein concentration adjusted to $1.0 \mathrm{mg} \mathrm{ml}^{-1}$.

The incubation assay was performed essentially according to Tocher \& Sargent (1984) and Bogevik et al. (2007). In brief, a solution of $0.2 \mathrm{ml}$ enzyme extract was added to $0.1 \mathrm{ml}$ of the substrate suspension and $0.1 \mathrm{ml}$ of $80 \mathrm{mM}$ sodium taurocholate (Sigma-Aldrich, St. Louis, USA), giving a total volume of $0.4 \mathrm{ml}$. The mixture was then incubated for $4 \mathrm{hrs}$ at ambient temperature of the fish $\left(10{ }^{\circ} \mathrm{C}\right)$ and the reaction terminated by the addition of $1.5 \mathrm{ml}$ of chloroform/methanol/ toluene (2:2.4:1, by vol.) containing $0.3 \mathrm{mM}$ oleic acid as a carrier. Fifty $\mu 1$ of $1 \mathrm{M} \mathrm{NaOH}$ was then added to ensure partitioning of all free fatty acids into the aqueous phase. The tubes were vortexed for $15 \mathrm{sec}$ and centrifuged at $3220 \mathrm{xg}$ for $30 \mathrm{~min}$ before $400 \mu \mathrm{l}$ of the aqueous phase was transferred to scintillation vials. After addition of $2.5 \mathrm{ml}$ of scintillation fluid (Opi-fluor, PerkinElmer, Wellesley, MA, USA), radioactivity was determined in a Packard Tri-Carb 2300TR liquid scintillation spectrophotometer. Results were calculated and expressed as pmol oleic acid produced $\min ^{-1} \mathrm{mg}$ protein ${ }^{-1}$ as described previously (Tocher \& Sargent, 1984).

\section{Calculations and statistical treatment}

Specific growth rate (SGR) was estimated according to the formula:

$$
\mathrm{SGR}=100 \times\left[(\ln (\text { end wt })-\ln (\operatorname{start} \mathrm{wt})] \Delta t^{-1}\right.
$$


Where end $\mathrm{wt}=$ final weight of fish, start $\mathrm{wt}=$ initial weight of fish and $\Delta t=$ duration of experiment in days.

The apparent digestibility coefficient (ADC) of nutrients was estimated according to the formula:

$$
\mathrm{ADC}=100-100 \times\left[\left(Y_{\text {feed }} Y_{\text {feces }}^{-1}\right) \mathrm{x}\left(N_{\text {feces }} N_{\text {feed }}^{-1}\right)\right]
$$

Where $Y_{\text {feed }}=$ concentration of yttrium oxide in feed, $Y_{\text {feces }}=$ concentration of yttrium in faeces, $N_{\text {feces }}=$ nutrient in faeces, $N_{\text {feed }}=$ nutrient in feed. All data were based on calculated wet weight of the sample. Fatty acid/long-chain alcohol digestibility data were based on the amount of the individual component in $\mu \mathrm{g} \mathrm{mg}^{-1}$ of total lipid.

$\mathrm{K}_{\text {factor }}$ was estimated according to:

$$
\mathrm{K}_{\text {factor }}=\mathrm{wt}(\mathrm{Lth})^{-3}
$$

Where wt is fish weight in grams, and Lth is fork length of the fish in $\mathrm{cm}$.

Feed conversion ratio (FCR) was estimated as:

$$
F C R=\Delta \text { feed intake }(\Delta \text { growth })^{-1}
$$

Where $\Delta$ feed is the amount of feed in grams consumed by fish between each weighting of the fish, and $\Delta$ growth is the increase of fish biomass during the same period.

Growth was monitored from all the individuals in the tanks. All statistical analysis was performed using STATISTICA 7.1 software for Windows (StatSoft. Inc., Tulsa, USA). Data were subjected to General Linear model analysis and Turkey's multiple range test (where appropriate) where significance was accepted at $P<0.05$. Feed conversion and digestibility analysis were obtained from triplicate tanks $(n=3)$ and these were subjected to multiple regression where significance 
was accepted at $P<0.05$.

\section{Results}

\section{Diets}

The total lipid level of the diets was 265, 257 and $250 \mathrm{~g} \mathrm{~kg}^{-1}$ for the control, mixed and Calanus diets, respectively (Table 2). The lipid class composition of the control diet differed from that of the diets with Calanus oil, particularly in terms of the neutral lipid components. The major lipid class of the control diet was TAG, which accounted for more than $590 \mathrm{~g} \mathrm{~kg}^{-1}$ of the total lipid with free fatty acids (FFA) and cholesterol, making up most of the remaining neutral lipids, followed by total phospholipids (Table 2). The total lipid of the diets supplemented with Calanus oil, on the other hand, contained approx. 310 and $480 \mathrm{~g} \mathrm{~kg}^{-1} \mathrm{WE}$, while TAG accounted for $340 \mathrm{~g}$ $\mathrm{kg}$ and $11 \mathrm{~g} \mathrm{~kg}^{-1}$ of the dietary lipid for mixed and Calanus diets, respectively. The remaining lipid classes were to a large extent similar to that of the control diet being mainly FFA, followed by total phospholipids and cholesterol (Table 2). Overall, the fatty acid composition of the diets were quite similar in relative amounts except for a notably higher level of monounsaturated fatty acids, mainly $22: 1 n-11$ and to a less extent 20:1n-9 and 18:1n-9 in the control diet, and a higher portion of 18:4n-3 in the Calanus oil diet (Table 3). However, the diets containing Calanus oil also contained fatty alcohols rich in 22:1n-11 and 20:1n-9 fatty chains (Table 3).

\section{Growth}

Smolts fed the control diet grew from $253 \mathrm{~g}$ to $537 \mathrm{~g}$ during the 100 day trial giving a daily specific growth rate (SGR) of 0.74 (Table 4). This was the same as those maintained on the mixed diet (SGR; 0.71) and significantly better than those maintained on the Calanus diet that grew from $255 \mathrm{~g}$ to $503 \mathrm{~g}$ with an SGR of 0.67 . Increase in fork length was similar between the 
dietary treatments increasing from $28 \mathrm{~cm}$ to $35 \mathrm{~cm}$ during the trial for all groups, while $\mathrm{K}$ factors were slightly increased at the end of the trial, with the Calanus group showing a significantly lower $\mathrm{K}$ factor than the mixed lipid group (Table 4).

\section{Feed conversion and digestion}

The FCR did not appear to be significantly affected by dietary treatment, being 1.3 and 1.1 for control group and Calanus group, respectively (Table 4).

The moisture contents of faeces from fish fed the control and mixed diets were $870 \mathrm{~g} \mathrm{~kg}^{-1}$, which was slightly higher than that of faeces from fish fed the Calanus oil diet $\left(850 \mathrm{~g} \mathrm{~kg}^{-1}\right)$ (Table 2). Faeces protein was similar between the dietary treatments while the dry lipid content in faeces from fish fed the Calanus diet $\left(170 \mathrm{~g} \mathrm{~kg}^{-1}\right)$ was almost double that of faeces from fish fed the control and mixed diets $\left(90 \mathrm{~g} \mathrm{~kg}^{-1}\right)$ (Table 2). The WE content of the faeces from fish fed the Calanus oil supplemented diets was 180 and $360 \mathrm{~g} \mathrm{~kg}^{-1}$ of total lipid in fish fed the mixed and Calanus diets, respectively, compared to 310 and $480 \mathrm{~g} \mathrm{~kg}^{-1}$ in the diets themselves. TAG accounted for 360, 110 and $90 \mathrm{~g} \mathrm{~kg}^{-1}$ in the faecal lipids in fish fed the control, mixed and Calanus diets, respectively, compared to 580, 340 and $110 \mathrm{~g} \mathrm{~kg}^{-1}$ in the respective diets. The level of free fatty acids in the faecal lipid was $410 \mathrm{~g} \mathrm{~kg}^{-1}$ in the control group compared to 290 and $150 \mathrm{~g} \mathrm{~kg}^{-1}$ in fish fed the mixed and Calanus diets, respectively. In addition, in fish fed the latter diets, $120-160 \mathrm{~g} \mathrm{~kg}^{-1}$ of the faecal lipid was fatty alcohol. Irrespective of dietary treatment, faecal lipid was characterised by increased proportions of saturated fatty acids, and a reduced proportions of PUFA, compared to the corresponding dietary lipid (Table 3). In contrast, the level of monounsaturated fatty acids in faecal lipids was similar to that of the corresponding diets. For fatty alcohols, however, compared to the dietary proportions, there were reduced proportions of both PUFA and saturated fatty acids in the faeces along with notably increased proportions of the 
long-chain monounsaturated alcohols, especially 22:1n-11, in fish fed the diets containing Calanus oil (Table 3).

Dietary treatment had no effect on the digestibility of total protein (Table 5). In contrast, total lipid digestibility was significantly lower in fish fed the Calanus diet (85\%) compared to fish fed the mixed and control diets (92\%). Digestibility of total fatty acids was $20 \%$ higher in the fish fed the control and mixed diets compared to fish fed the Calanus diet, with lowest digestibility observed with saturated fatty acids (90 vs. 58\%) and highest digestibility observed with PUFA (96 vs. 86\%) (Table 5). Saturated fatty alcohols were better utilized than the corresponding fatty acids in fish fed both diets containing Calanus oil, and most of the other alcohols, except for 18:1n-9, were better utilized than corresponding fatty acids in fish fed the Calanus diet (Table 5).

Further results will only compare fish fed the control and Calanus diets, as fish fed the mixed diet only had minor variations in growth and nutritional utilization compared to the control group.

\section{Bile composition}

The fish fed the control diet displayed significantly lower bile volumes $(0.8 \mathrm{v} .1 .1 \mathrm{ml})$ than fish maintained on the Calanus diet (Table 6). This was also evident when fish weights were taken into account, with bile volume being $1.4 \mathrm{ml} \mathrm{kg}^{-1}$ in fish fed the control diet compared to $1.9 \mathrm{ml}$ $\mathrm{kg}^{-1}$ for fish fed the Calanus diet. The concentration of conjugated bile salts in the bile (460-480 $\mathrm{mM}$ ) was not significantly different between fish fed the control and Calanus diets (Table 6). Irrespective of dietary treatment, the main bile salt was taurocholate (TC), which accounted for more than $90 \%$ of the identified bile salts, with the remainder being mainly taurochenodeoxycholate (TCDC). Dietary treatment did not significantly influence the total protein concentration $\left(15-16 \mathrm{~g} \mathrm{~kg}^{-1}\right)$, total lipid concentration $\left(16-18 \mathrm{~g} \mathrm{~kg}^{-1}\right)$ or the osmolality (314 - $332 \mathrm{mOsm} \mathrm{kg} \mathrm{kH}_{2} \mathrm{O}$ ) of the bile. In contrast, the total phospholipid concentration of the 
bile was significantly higher in fish the Calanus oil diet ( 0.28 v. $0.22 \mathrm{mg} \mathrm{L}^{-1}$ bile) compared to fish fed the control diet (Table 6). Analysis of the bile lipid extracts by HPTLC showed that the main lipid classes in bile were cholesterol, followed by phosphatidylcholine (data not shown).

\section{Lipolytic activities}

Irrespective of dietary treatment, the rank order for lipid hydrolase activities in the midgut luminal contents was triacylglycerol hydrolyses $(\mathrm{TAGH})>$ wax ester hydrolyses $(\mathrm{WEH})>$ sterol ester hydrolyses (SEH) (Table 7). All the lipid hydrolase activities were higher in intestinal contents from fish fed the Calanus diet compared to fish fed the control diet (Table 7). This effect was significant for both WEH and SEH activities. Thus, in fish fed the Calanus diet, the hydrolase activity towards WE and SE was increased relative to that towards TAG compared to fish fed the control diet.

\section{Discussion}

The present study showed a marginal, but significantly, lower SGR when salmon smolts were fed a diet where Calanus oil completely replaced fish oil compared to the fish oil control diet, which appears to be in contrast to previous results (Olsen et al. 2004). However, in the earlier trial, the fish were considerably larger than those in the present study with, final weights above $1.5 \mathrm{~kg}$. It is possible that the ability to adapt to diets containing Calanus oil is, to some extent, related to size or age of fish. In addition, WE contributed up to $480 \mathrm{~g} \mathrm{~kg}^{-1}$ of the total dietary lipid in the present trial, compared to around only $370 \mathrm{~g} \mathrm{~kg}^{-1}$ in the previous study (Olsen et al. 2004). Consistent with this argument, the mixed diet in the present study contained $310 \mathrm{~g} \mathrm{~kg}^{-1}$ of the dietary lipid as WE, and the fish fed this diet showed the same growth as the control group. These data indicate 
that optimal utilization of WE in practical diets may have an upper limit of dietary WE content, closer to 370 than $470 \mathrm{~g} \mathrm{~kg}^{-1}$ of dietary lipid. The lower SGR in fish fed the Calanus diet was accompanied by increased faecal lipid content and reduced ADC of lipid. Previously, Lie \& Lambertsen (1991) showed a 2 to 3-fold increase in faecal lipid in cod (Gadus morhua) fed a diet supplemented with Calanus oil compared to fish fed a diet containing fish oil. These observations probably relate to lower specific activity of WEH compared to TAGH, which could result in reduced lipid absorption. Slower hydrolysis of WE than TAG has also been observed in other fish species including anchovy (Engraulis mordax), rainbow trout and cod (Patton et al., 1975; Tocher \& Sargent, 1984; Lie \& Lambertsen, 1985). However, salmon fed a diet containing 300$400 \mathrm{~g} \mathrm{~kg}^{-1}$ of the dietary lipid as WE, appear to be capable to adapt the digestive capacity to maintain a high rate of utilization and ADC of total lipid at the same level as fish maintained on a fish oil diet (Olsen et al. 2004). The significantly lower digestibility of lipids in the fish fed a higher level of WE are most likely due to incomplete lipid micelle solubilisation at increased ratio of non-polar lipids in the intestinal lumen.

Salmon fed increasing WE levels seem to adapt their digestion in several ways that may result in enhanced lipid digestibility. Firstly, the fasting gallbladder bile volume increased from $1.37 \mathrm{ml}$ $\mathrm{kg}^{-1}$ fish to $1.88 \mathrm{ml} \mathrm{kg}^{-1}$ upon WE feeding, without affecting the bile salt concentration. The composition of the bile was unchanged by dietary treatment, with osmolality remaining constant, indicating no change in ionic composition. This means that the increased bile volume was not simply achieved by producing a larger volume of more dilute bile. As a result, the total available bile salts and phospholipids for lipid emulsification during digestion were increased. This agrees with previous work in rainbow trout fed a diet rich in WE, where it was speculated that the increased bile volume was likely to result from a direct effect of increased lipid load and/or increased bile salt concentration in the gut lumen (Tocher \& Sargent, 1984). In humans, 
increased dietary fat increased gallbladder volume, emptying and turnover of bile in the enterohepatic circulation and, consequently, increased the amount of bile for the emulsification process during digestion (Dowling 1973; Froehlich et al. 1995).

Gall-bladder bile in rainbow trout fed a fish oil diet was composed of bile salts together with protein, cholesterol and a trace amount of phospholipids (Tocher \& Sargent 1984). The overall composition of Atlantic salmon bile in the present study was found to contain around $470 \mathrm{mM}$ bile salts, $15 \mathrm{~g} \mathrm{~kg}^{-1}$ protein, and $17 \mathrm{~g} \mathrm{~kg}^{-1}$ lipid including about $0.2 \mathrm{mg}$ phospholipids $\mathrm{L}^{-1}$ bile. A similar composition, including possible sulphate derivatives, was also reported in bile from wild leopard shark, Triakus semifasciata (Patton et al. 1977). The bile salt composition of salmon bile in the present study did not change with diet and was shown to contain just two main components, namely TC at around $400 \mathrm{mM}$ and TCDC at about $40 \mathrm{mM}$, a ratio of 10:1. This is consistent with juvenile rainbow trout gall bladder bile, where TC and TCDC were found to be the main components and at a similar ratio albeit at lower concentrations (200 and $20 \mathrm{mM}$, respectively), with neither concentration nor ratio changing with dietary treatment including WE feeding (Tocher \& Sargent 1984). Other trials have also shown that TC and TCDC were the main bile salts in salmonids in ratios of 8:1 in Arctic charr, Salvelinus alpinus L. (Gislason et al. 1996), and 6:1 in an early study in rainbow trout (Denton \& Yousef, 1974).

The second apparent adaptation to feeding diets with elevated WE was the increase in mid-gut lipolytic activities. This finding was irrespective of the increased bile volume and bile salt found, since the assays were performed on desalted extracts at a constant bile salt (TC) concentration. This response seem to rely on increased production and secretion of lipases (or hydrolases). Increased lipolytic activity has also been suggested earlier as a response to increased dietary lipid content (Borlongan, 1990; Bazaz \& Keshavanath 1993) and WE feeding in wild fish (Mankura et al. 1984) and rainbow trout (Tocher \& Sargent, 1984). 
In conclusion, the present study demonstrates that Atlantic salmon in seawater effectively utilize diets with WE up to approx $30 \%$ of the dietary lipids. Lower lipid digestibility and growth were observed when the level of WE approached $50 \%$ of the total dietary lipid. However, salmon seem to be able to adapt to increased dietary intake of WE by increasing bile production for lipid emulsification and enzymatic activities for lipid hydrolysis. Further studies to examine the long term effect of feeding a wax ester rich diet to salmon, together with a thoroughly ecological survey of the potential impact of a harvest of Calanus finmarchicus should be undertaken to maximize the potential of this marine oil.

\section{Acknowledgement}

The project was supported from the Norwegian Research Council (no. 165051/S40). The formulation of the diets of Harald Mundheim, Norwegian Institute of Fisheries and Aquaculture Research, (Fyllingsdalen, Norway), technical assistance of Arnor Gullanger, Ivar Helge Matre and Atle Vågseth, IMR (Matre, Norway), Jacob Wessels (NIFES, Bergen, Norway) and the lipid analysis assistance of Dr. Jim Henderson, University of Stirling (Stirling, Scotland) are gratefully acknowledged.

\section{References}

AOAC Official Methods of Analysis (1995), 16 th. Ed. Metode 992.15: Crude protein in meat and meat products, combustion method.

Bauermeister, A. \& Sargent, J.R. (1979) Wax esters - Major metabolites in the marineenvironment. Trends In Biochemical Sciences, 4, 209-211.

Bazaz, M.M. \& Keshavanath, P. (1993) Effect of feeding different levels of sardine oil on growth, muscle composition and digestive enzyme-activities of Mahseer, Tor-Khudree. 
Aquaculture, 115, 111-119.

Bogevik, A.S., Tocher, D.R., Waagbø, R. \& Olsen. R.E. (2007) Triacylglycerol, wax ester and sterol ester hydrolase in midgut of Atlantic salmon (Salmo salar). Aquacult. Nutr. In Press.

Borlongan, I.G. (1990) Studies on the digestive lipases of Milkfish, Chanos-Chanos. Aquaculture, 89, 315-325.

Coca, E., Ribas, B., Trigueros, G., Mtnezsarmiento, J., Borque, M., Ortega, D., Sobrino, A., Mallen, A., Depablos, I. \& Fdezrepresa, J.A. (1994) A method for quick determination of bile-acids in bile of patients with biliary lithiasis. Journal Of Liquid Chromatography, 17, $1349-1363$.

Cohen, D.E. (1996) Hepatocellular transport and secretion of biliary phospholipids. Seminar in liver disease, 16, 191-200.

Dalpadado, P., Ellertsen, B., Melle, W. \& Skjoldal, H.R. (1998) Summer distribution patterns and biomass estimates of macrozooplankton and micronekton in the Nordic Seas. Sarsia, 83, 103-116.

Denton, J.E., Yousef, M.K., Yousef, I.M. \& Kuksis, A. (1974) Bile-acid composition of rainbowtrout, Salmo-Gairdneri. Lipids, 9, 945-951.

Dowling, R. M. (1973) The enterohepatic circulation of bile acids as they relate to lipid disorders. J. Clin. Pathol. Suppl. (Assoc. Clin. Pathol.), 5, 59-67.

Falk-Petersen, S., Hagen, W., Kattner, G., Clarke, A. \& Sargent, J. (2000) Lipids, trophic relationships, and biodiversity in Arctic and Antarctic krill. Canadian Journal Of Fisheries And Aquatic Sciences, 57, 178-191.

Falk-Petersen, S., Sargent, J.R., Hopkins, C.C.E. \& Vaja, B. (1982) Ecological investigations on the zooplankton community of Balsfjorden, Northern Norway - Lipids in the Euphausiids Thysanoessa-Raschi and Thysanoessa-Inermis during spring. Marine Biology, 68, 97-102. 
Food And Agricultural Organisation (FAO) (2006) State of world aquaculture 2006. FAO Fisheries Technical Paper No. 500. 134 pp. FAO, Rome.

Farquhar, J.W. (1962) Human erythrocyte phosphoglycerides .1. Quantification of plasmalogens, fatty acids and fatty aldehydes. Biochimica Et Biophysica Acta, 60, 80-\&.

Folch, J., Lees, M. \& Stanley, G.H.S. (1957) A simple method for the isolation and purification of total lipides from animal tissues. Journal Of Biological Chemistry, 226, 497-509.

Froehlich, F., Gonvers, J.J. \& Fried, M. (1995) Role of nutrient fat and cholecystokinin in regulation of gallbladder emptying in man. Digestive Diseases and Sciences, 40, 529-533.

Gislason, G., Olsen, R.E., Ringø, E. (1996) Comparative effects of dietary $\mathrm{Na}^{+}$-lactate on Arctic char, Salvelinus alpinus L. and Atlantic salmon, Salmo salar L . Aquacult. Res., 27, 429435.

Kattner, G. \& Krause, M. (1987) Changes in lipids during the development of Calanusfinmarchicus from copepodid-I to adult. Marine Biology, 96, 511-518.

Lie, O. \& Lambertsen, G. (1985) Digestive lipolytic enzymes in cod (Gadus-morhua) - fatty-acid specificity. Comparative Biochemistry and Physiology B-Biochemistry \& Molecular Biology, 80, 447-450.

Lie, O. \& Lambertsen, G. (1991) Lipid digestion and absorption in cod (Gadus-morhua), comparing triacylglycerols, wax esters and diacylalkylglycerols. Comparative Biochemistry and Physiology A-Physiology, 98, 159-163.

Lowry, O.H., Rosebrough, N.J., Farr, A.L. \& Randall, R.J. (1951) Protein measurement with the folin phenol reagent. Journal Of Biological Chemistry, 193, 265-275.

Madden, H., Beare, D., Heath, M.R., Fraser, J.G. \& Gallego, A. (1999) The sping/early summer distribution of Calanus spp. in the northern North Sea and adjacent areas. Fisheries Oceanography, 8, 138-152. 
Mankura, M., Iijima, N., Kayama, M. \& Aida, S. (1987) Lipid transport mechanism in the fish. 3. Plasma transport form and metabolism of dietary fatty alcohol and wax ester in carp. Nippon Suisan Gakkaishi, 53, 1221-1230.

Olsen, R.E. \& Henderson, R.J. (1989) The rapid analysis of neutral and polar marine lipids using double-development hptlc and scanning densitometry. Journal of Experimental Marine Biology and Ecology, 129, 189-197.

Olsen, R.E., Henderson, R.J., Sountama, J., Hemre, G., Ringo, E., Melle, W. \& Tocher, D.R. (2004) Atlantic salmon, Salmo salar, utilizes wax ester-rich oil from Calanus finmarchicus effectively. Aquaculture, 240, 433-449.

Olsen, R.E., Myklebust, R., Kaino, T. \& Ringo, E. (1999) Lipid digestibility and ultrastructural changes in the enterocytes of Arctic char (Salvelinus alpinus L.) fed linseed oil and soybean lecithin. Fish Physiology And Biochemistry, 21, 35-44.

Otterå, H., Garatun-Tjeldsto, O., Julshamn, K. \& Austreng, E. (2003) Feed preferences in juvenile cod estimated by inert lanthanid markers - effects of moisture content in the feed. Aquaculture International, 11, 217-224.

Palmquist, D.L. \& Jenkins, T.C. (2003) Challenges with fats and fatty acid methods. Journal Of Animal Science, 81, 3250-3254.

Patton, Warner \& Benson (1977) Partial caracterization of the bile salt-dependent triglycerol lipase from the leopard shark pancres. Biochimica Biophysica Acta, 486, 322-330.

Patton, J.S. \& Benson, A.A. (1975) Comparative study of wax ester digestion in fish. Comparative Biochemistry And Physiology B-Biochemistry \& Molecular Biology, 52, 111116. 
Patton, J.S., Nevenzel, J.C. \& Benson, A.A. (1975) Specificity of digestive lipases in hydrolysis of wax esters and triglycerides studied in anchovy and other selected fish. Lipids, 10, 575583.

Place, A.R. (1992) comparative aspects of lipid digestion and absorption - physiological correlates of wax ester digestion. American Journal Of Physiology, 263, R464-R471.

Rikardsen, A.H., Haugland, M., Bjorn, P.A., Finstad, B., Knudsen, R., Dempson, J.B., Holst, J.C., Hvidsten, N.A. \& Holm, M. (2004) Geographical differences in marine feeding of Atlantic salmon post-smolts in Norwegian fjords. Journal Of Fish Biology, 64, 1655-1679.

Saether, O. \& Mohr, V. (1987) Chemical-composition of North-Atlantic krill. Comparative Biochemistry And Physiology B-Biochemistry \& Molecular Biology, 88, 157-164.

Sargent, J.R., Lee, R.F. \& Nevenzel, J.C. (1976) Marine wax esters, In The Chemistry and Biochemistry of Natural Waxes (Ed. P. Kolattukudy), Elsvier, Amsterdan, pp. 50-91.

Tocher, D.R. \& Harvie, D.G. (1988) Fatty-acid compositions of the major phosphoglycerides from fish neural tissues - (n-3) and (n-6) poly-unsaturated fatty-acids in rainbow-trout (Salmo-gairdneri) and cod (Gadus-morhua) brains and retinas. Fish Physiology And Biochemistry, 5, 229-239.

Tocher, D.R. \& Sargent, J.R. (1984) studies on triacylglycerol, wax ester and sterol ester hydrolases in intestinal ceca of rainbow-trout (Salmo-gairdneri) fed diets rich in triacylglycerols and wax esters. Comparative Biochemistry And Physiology B-Biochemistry \& Molecular Biology, 77, 561-571.

\section{Tables}

Table 1. Formulation $\left(\mathrm{g} \mathrm{kg}^{-1}\right.$ diet) of the experimental diets 


\begin{tabular}{lccc}
\hline & Control & Mixed & Calanus oil \\
\hline Fish meal 24/05+6/05 (1:1) & 596 & 596 & 596 \\
Fish oil & 230 & 115 & 0 \\
Calanus oil & 0 & 115 & 230 \\
Wheat 153/05 & 160 & 160 & 160 \\
Vitamin mixture $^{\mathrm{a}}$ & 10 & 10 & 10 \\
Mineral mixture $^{\mathrm{b}}$ & 4.0 & 4.0 & 4.0 \\
Carophyll pink $(8 \%)^{\text {Yttrium oxide }\left(\mathrm{Y}_{2} \mathrm{O}_{3}\right)}$ & 0.3 & 0.3 & 0.3 \\
\hline
\end{tabular}

${ }^{a}$ Diets supplied with following vitamins per kg diet: vitamin D3, 3000 I.E; vitamin E (Rovimix, 50\%), 160mg; thiamine, 20mg; riboflavin, 30mg; pyridoxine- $\mathrm{HCl}$, 25mg; vitamin C (Riboflavin Stay C 35\%), 200mg; calcium pantothenate, 60mg; biotin, $1 \mathrm{mg}$; folic acid, 10mg; niacin, 200mg; vitamin $\mathrm{B}_{12}, 0.05 \mathrm{mg}$; menadione bisulphate, $20 \mathrm{mg}$.

${ }^{\mathrm{b}}$ Diets supplied with following minerals per kg diet: magnesium, 500mg; potassium, 400mg; zinc, 80mg; iron, 50 $\mathrm{mg}$; manganese, $10 \mathrm{mg}$; copper, $5 \mathrm{mg}$. 
Table 2. Proximate composition $\left(\mathrm{g} \mathrm{kg}^{-1}\right)$ and lipid class composition $\left(\mathrm{g} \mathrm{kg}^{-1}\right.$ of total lipid) of diets and faeces of Atlantic salmon fed control fish oil, mixed or Calanus oil diets. Means of 3 replicates \pm S.D.

\begin{tabular}{|c|c|c|c|c|c|c|}
\hline & \multicolumn{2}{|c|}{ Control diet } & \multicolumn{2}{|c|}{ Mixed diet } & \multicolumn{2}{|c|}{ Calanus oil diet } \\
\hline & Diet & Faeces & Diet & Faeces & Diet & Faeces \\
\hline Dry matter & 924 & $128 \pm 6$ & 930 & $132 \pm 6$ & 922 & $150 \pm 9$ \\
\hline Total dry fat & 264 & $90 \pm 24$ & 257 & $85 \pm 27$ & 250 & $171 \pm 51$ \\
\hline Total dry protein & 481 & $131 \pm 31$ & 478 & $102 \pm 21$ & 492 & $124 \pm 35$ \\
\hline \multicolumn{7}{|l|}{$\underline{\text { Lipid class }}$} \\
\hline Triacylglycerol & 580 & $356 \pm 88$ & 339 & $105 \pm 72$ & 112 & $86 \pm 06$ \\
\hline Wax ester & - & - & 307 & $178 \pm 59$ & 477 & $363 \pm 07$ \\
\hline Free fatty alcohol & - & - & 0 & $156 \pm 27$ & - & $116 \pm 03$ \\
\hline Free fatty acid & 146 & $408 \pm 77$ & 165 & $290 \pm 61$ & 197 & $152 \pm 13$ \\
\hline Cholesterol $^{\mathrm{a}}$ & 113 & $114 \pm 05$ & 91 & $93 \pm 27$ & 81 & $187 \pm 13$ \\
\hline Sterol ester & 59 & - & - & - & - & - \\
\hline Total polar lipid & 71 & $122 \pm 22$ & 65 & $178 \pm 39$ & 91 & $95 \pm 19$ \\
\hline Pigment $^{\mathrm{b}}$ & 30 & $99 \pm 36$ & 33 & $103 \pm 35$ & 42 & $41 \pm 08$ \\
\hline
\end{tabular}

${ }^{a}$ May contain some diacylglycerol

${ }^{\mathrm{b}}$ May contain some monoacylglycerol 
Table 3. Total fatty acid and total fatty alcohol compositions (of weight) of diets, and faeces of Atlantic salmon fed control (fish oil), mixed or Calanus diets. Means of 3 replicates \pm S.D.

\begin{tabular}{|c|c|c|c|c|c|c|c|c|c|c|}
\hline & \multicolumn{10}{|c|}{ Composition (wt. $\mathrm{g} \mathrm{kg}^{-1}$ ) of fatty acids and long-chain alcohols in diet and faeces } \\
\hline & \multicolumn{2}{|c|}{ Control diet } & \multicolumn{4}{|c|}{ Mixed diet } & \multicolumn{4}{|c|}{ Calanus oil diet } \\
\hline & \multicolumn{2}{|c|}{ Fatty acid } & \multicolumn{2}{|c|}{ Fatty acid } & \multicolumn{2}{|c|}{ Fatty alcohol } & \multicolumn{2}{|c|}{ Fatty acid } & \multicolumn{2}{|c|}{ Fatty alcohol } \\
\hline & Diet & Feces & Diet & Feces & Diet & Feces & Diet & Feces & Diet & Feces \\
\hline $14: 0$ & 46 & $92 \pm 6$ & 80 & $123 \pm 8$ & 16 & $7 \pm 1$ & 98 & $201 \pm 26$ & 13 & $6 \pm 1$ \\
\hline $16: 0$ & 136 & $237 \pm 23$ & 132 & $219 \pm 28$ & 104 & $52 \pm 8$ & 146 & $211 \pm 7$ & 99 & $56 \pm 7$ \\
\hline 18:0 & 16 & $32 \pm 4$ & 14 & $27 \pm 3$ & 33 & $20 \pm 4$ & 13 & $19 \pm 1$ & 29 & $3 \pm 3$ \\
\hline $16: 1 n-7$ & 47 & $30 \pm 6$ & 51 & $28 \pm 4$ & 18 & $10 \pm 3$ & 44 & $25 \pm 4$ & 16 & $9 \pm 1$ \\
\hline $18: 1 n-9$ & 86 & $68 \pm 6$ & 83 & $59 \pm 5$ & 14 & $9 \pm 2$ & 67 & $50 \pm 3$ & 14 & $19 \pm 2$ \\
\hline $20: 1 n-9$ & 101 & $107 \pm 3$ & 98 & $101 \pm 11$ & 289 & $286 \pm 7$ & 76 & $75 \pm 3$ & 294 & $301 \pm 11$ \\
\hline $22: 1 n-11$ & 142 & $176 \pm 5$ & 131 & $173 \pm 19$ & 386 & $516 \pm 33$ & 102 & $124 \pm 10$ & 420 & $514 \pm 20$ \\
\hline $22: 1 n-9$ & 09 & $12 \pm 2$ & 7 & $13 \pm 1$ & 15 & $8 \pm 5$ & 6 & $9 \pm 1$ & 4 & $2 \pm 0$ \\
\hline $24: 1 n-9$ & 66 & $27 \pm 7$ & 9 & $27 \pm 5$ & 64 & $61 \pm 5$ & 10 & $17 \pm 1$ & 53 & $51 \pm 2$ \\
\hline $18: 2 n-6$ & 51 & $28 \pm 1$ & 26 & $26 \pm 7$ & 24 & $12 \pm 4$ & 27 & $23 \pm 3$ & 22 & $13 \pm 2$ \\
\hline $20: 4 n-6$ & 3 & $3 \pm 0$ & 4 & $3 \pm 0$ & - & - & 3 & $2 \pm 0$ & - & - \\
\hline $18: 3 n-3$ & 25 & $9 \pm 2$ & 23 & $9 \pm 2$ & 36 & $17 \pm 5$ & 27 & $13 \pm 3$ & 34 & $19 \pm 3$ \\
\hline $18: 4 n-3$ & 43 & $15 \pm 6$ & 78 & $17 \pm 6$ & - & - & 129 & $47 \pm 14$ & - & - \\
\hline $20: 4 n-3$ & 11 & $5 \pm 2$ & 12 & $4 \pm 1$ & - & - & 10 & $5 \pm 1$ & - & - \\
\hline $20: 5 n-3$ & 76 & $35 \pm 9$ & 85 & $32 \pm 6$ & - & - & 92 & $43 \pm 9$ & - & - \\
\hline $22: 5 n-3$ & 4 & $5 \pm 1$ & 8 & $5 \pm 1$ & - & - & 8 & $5 \pm 1$ & - & - \\
\hline $22: 6 n-3$ & 105 & $83 \pm 10$ & 121 & $96 \pm 7$ & - & - & 108 & $91 \pm 6$ & - & - \\
\hline $\mathrm{SAT}^{1}$ & 207 & $373 \pm 33$ & 234 & $384 \pm 41$ & 153 & $80 \pm 11$ & 273 & $449 \pm 31$ & 141 & $65 \pm 7$ \\
\hline $\mathrm{MONO}^{2}$ & 468 & $441 \pm 5$ & 401 & $419 \pm 30$ & 788 & $891 \pm 19$ & 318 & $315 \pm 12$ & 803 & $903 \pm 12$ \\
\hline n-6 PUFA & 61 & $34 \pm 2$ & 36 & $32 \pm 6$ & 24 & $12 \pm 4$ & 33 & $31 \pm 4$ & 22 & $13 \pm 2$ \\
\hline n-3 PUFA & 264 & $152 \pm 31$ & 32.9 & $165 \pm 20$ & 36 & $17 \pm 5$ & 375 & $205 \pm 32$ & 34 & $19 \pm 3$ \\
\hline PUFA $^{3}$ & 325 & $186 \pm 32$ & 36.5 & $198 \pm 20$ & 60 & $30 \pm 8$ & 408 & $236 \pm 33$ & 56 & $32 \pm 4$ \\
\hline
\end{tabular}

${ }^{1} \mathrm{SAT}=$ saturated fatty acids $;{ }^{2} \mathrm{MONO}=$ monounsaturated fatty acids $;{ }^{3} \mathrm{PUFA}=$ poly unsaturated fatty acids 
Table 4. Growth performance, specific growth rate (SGR) and feed conversion ratio (FCR) of Atlantic salmon fed the control (fish oil), mixed and Calanus diets over 100 days. Means \pm S.D. (n=3). Values with different superscript letter are significantly different $(P<0.05)$ as determined by nested ANOVA followed by the Tukey post hoc test.

\begin{tabular}{lccc}
\hline & Control diet & Mixed diet & Calanus oil diet \\
\hline Initial weight & $253 \pm 15$ & $252 \pm 17$ & $255 \pm 17$ \\
Final weight & $537 \pm 84$ & $518 \pm 68$ & $503 \pm 65$ \\
Initial length & $28.0 \pm 0.6$ & $27.9 \pm 0.8$ & $28.0 \pm 0.6$ \\
Final length & $34.9 \pm 2.0$ & $34.4 \pm 1.7$ & $34.5 \pm 1.5$ \\
Initial K factor & $1.16 \pm 0.06$ & $1.17 \pm 0.07$ & $1.17 \pm 0.06$ \\
Final K factor & $1.26 \pm 0.09^{\mathrm{ab}}$ & $1.27 \pm 0.09^{\mathrm{a}}$ & $1.22 \pm 0.07^{\mathrm{b}}$ \\
SGR & $0.74 \pm 0.16^{\mathrm{a}}$ & $0.71 \pm 0.12^{\mathrm{ab}}$ & $0.67 \pm 0.12^{\mathrm{b}}$ \\
FCR & $1.12 \pm 0.09$ & $1.13 \pm 0.17$ & $1.27 \pm 0.07$ \\
\hline
\end{tabular}


Table 5. Digestibility of dry matter, total lipid, total protein, total fatty acid and total fatty alcohol in Atlantic salmon fed control, mixed and Calanus diets. Means of 3 replicates \pm S.D.

\begin{tabular}{|c|c|c|c|c|c|}
\hline & \multirow{2}{*}{$\begin{array}{l}\text { Control diet } \\
\text { Fatty acid }\end{array}$} & \multicolumn{2}{|c|}{ Mixed diet } & \multicolumn{2}{|c|}{ Calanus diet } \\
\hline & & Fatty acid & Fatty alcohol & Fatty acid & Fatty alcohol \\
\hline Dry matter & $75.6 \pm 0.9$ & \multicolumn{2}{|c|}{$75.0 \pm 1.7$} & \multicolumn{2}{|c|}{$73.1 \pm 2.8$} \\
\hline Total lipid ${ }^{*}$ & $91.8 \pm 2.2$ & \multicolumn{2}{|c|}{$92.3 \pm 2.4$} & \multicolumn{2}{|c|}{$84.5 \pm 4.6$} \\
\hline Total protein & $92.8 \pm 1.7$ & \multicolumn{2}{|c|}{$94.2 \pm 1.4$} & \multicolumn{2}{|c|}{$92.5 \pm 3.0$} \\
\hline $14: 0^{a b}$ & $87.3 \pm 7.0$ & $90.6 \pm 5.2$ & $97.3 \pm 1.4$ & $47.7 \pm 12.9$ & $92.4 \pm 1.1$ \\
\hline $16: 0^{a b}$ & $89.1 \pm 5.7$ & $90.0 \pm 5.2$ & $97.3 \pm 1.4$ & $63.4 \pm 4.8$ & $91.3 \pm 1.3$ \\
\hline $18: 0^{\mathrm{a}}$ & $87.6 \pm 6.2$ & $88.1 \pm 6.1$ & $96.8 \pm 1.7$ & $63.2 \pm 4.3$ & $98.2 \pm 1.5$ \\
\hline $16: 1 n-7^{a b}$ & $95.6 \pm 3.4$ & $96.4 \pm 2.3$ & $97.1 \pm 1.6$ & $85.6 \pm 0.7$ & $91.3 \pm 1.5$ \\
\hline $18: 1 n-9^{a b}$ & $94.7 \pm 3.5$ & $95.4 \pm 3.0$ & $96.3 \pm 2.1$ & $81.3 \pm 1.0$ & $78.7 \pm 4.1$ \\
\hline $20: 1 n-9^{a b}$ & $93.1 \pm 4.2$ & $93.5 \pm 3.9$ & $94.6 \pm 2.6$ & $75.0 \pm 3.8$ & $83.9 \pm 3.8$ \\
\hline $22: 1 \mathrm{n}-11^{\mathrm{ab}}$ & $92.0 \pm 4.6$ & $91.7 \pm 4.8$ & $92.8 \pm 3.5$ & $69.1 \pm 5.8$ & $80.8 \pm 4.2$ \\
\hline $22: 1 n-9^{a b}$ & $92.4 \pm 3.3$ & $89.2 \pm 5.4$ & $97.2 \pm 2.4$ & $61.8 \pm 7.2$ & $92.9 \pm 0.9$ \\
\hline $24: 1 n-9^{a b}$ & $97.5 \pm 1.3$ & $83.0 \pm 7.3$ & $95.0 \pm 2.2$ & $58.5 \pm 6.7$ & $85.1 \pm 2.7$ \\
\hline $18: 2 n-6^{a b}$ & $96.6 \pm 1.9$ & $94.0 \pm 3.9$ & $97.1 \pm 1.8$ & $78.2 \pm 2.7$ & $90.8 \pm 1.6$ \\
\hline $20: 4 n-6^{a}$ & $94.1 \pm 4.1$ & $95.5 \pm 3.0$ & & $79.3 \pm 0.7$ & \\
\hline $18: 3 n-3^{a b}$ & $97.4 \pm 2.2$ & $97.3 \pm 2.0$ & $97.4 \pm 1.6$ & $87.8 \pm 1.2$ & $91.2 \pm 1.5$ \\
\hline $18: 4 n-3^{a}$ & $97.5 \pm 2.4$ & $98.4 \pm 1.3$ & & $91.1 \pm 1.9$ & \\
\hline $20: 5 n-3^{a}$ & $96.8 \pm 2.7$ & $97.4 \pm 1.9$ & & $88.3 \pm 1.3$ & \\
\hline $22: 5 n-3^{a}$ & $92.9 \pm 5.4$ & $96.1 \pm 2.8$ & & $84.3 \pm 0.6$ & \\
\hline $22: 6 n-3^{a}$ & $94.6 \pm 3.8$ & $95.0 \pm 3.1$ & & $78.9 \pm 1.2$ & \\
\hline $\mathrm{SAT}^{1 \mathrm{ab}}$ & $88.7 \pm 5.9$ & $90.0 \pm 5.3$ & $97.2 \pm 1.5$ & $58.2 \pm 7.7$ & $92.8 \pm 1.3$ \\
\hline $\mathrm{MONO}^{2 \mathrm{ab}}$ & $93.9 \pm 3.7$ & $93.4 \pm 3.9$ & $93.9 \pm 3.0$ & $74.9 \pm 3.5$ & $82.3 \pm 3.8$ \\
\hline$n-6$ PUFA $^{a b}$ & $96.3 \pm 2.3$ & $94.4 \pm 3.7$ & $97.1 \pm 1.8$ & $76.8 \pm 2.6$ & $90.8 \pm 1.6$ \\
\hline n-3 PUFA ${ }^{a b}$ & $96.0 \pm 3.1$ & $96.7 \pm 2.2$ & $97.4 \pm 1.6$ & $86.3 \pm 0.8$ & $91.2 \pm 1.5$ \\
\hline $\mathrm{PUFA}^{3}$ ab & $96.0 \pm 2.9$ & $96.5 \pm 2.4$ & $97.3 \pm 2.6$ & $85.5 \pm 0.5$ & $91.1 \pm 3.3$ \\
\hline Total $^{\mathrm{ab}}$ & $93.5 \pm 3.9$ & $93.7 \pm 3.7$ & $94.6 \pm 2.2$ & $74.7 \pm 3.0$ & $84.3 \pm 3.4$ \\
\hline
\end{tabular}

${ }^{1} \mathrm{SAT}=$ saturated fatty acids $;{ }^{2} \mathrm{MONO}=$ monounsaturated fatty acids $;{ }^{3} \mathrm{PUFA}=$ poly unsaturated fatty acids

${ }^{*}$ Significant differences in general digestibility as determined by multiple regressions $(P<0.05)$.

${ }^{a}$ Significant differences in digestibility of fatty acid as determined by multiple regressions $(P<0.05)$.

${ }^{\mathrm{b}}$ Significant differences in digestibility of fatty alcohol as determined by multiple regressions $(P<0.05)$. 
Table 6. Bile composition of Atlantic salmon fed the control and Calanus diets for 100 days. Means \pm S.D. of 3 replicates (each from ten individuals for bile volume and each from three individuals for bile composition). Values with different superscript letter are significantly different $(P<0.05)$ as determined by nested ANOVA followed by the Tukey post hoc test.

\begin{tabular}{|c|c|c|}
\hline & Control diet & Calanus diet \\
\hline$\overline{\text { Bile volume }\left(\mathrm{ml} \mathrm{fish}^{-1}\right)}$ & $0.88 \pm 0.37^{\mathrm{a}}$ & $1.12 \pm 0.32^{b}$ \\
\hline Bile volume $\left(\mathrm{ml} \mathrm{kg}^{-1}\right.$ fish $)$ & $1.37 \pm 0.40^{\mathrm{a}}$ & $1.88 \pm 0.44^{\mathrm{b}}$ \\
\hline $\mathrm{TC}^{1)}(\mathrm{mM})$ & $425 \pm 44$ & $443 \pm 34$ \\
\hline $\mathrm{TCDC}^{1)}(\mathrm{mM})$ & $36.7 \pm 10.6$ & $37.5 \pm 11.1$ \\
\hline $\mathrm{TC}+\mathrm{TCDC}(\mathrm{mM})$ & $462 \pm 53$ & $480 \pm 37$ \\
\hline Osmolality $\left(\mathrm{mOsm} \mathrm{kg}{ }^{-1} \mathrm{H}_{2} \mathrm{O}\right)$ & $327 \pm 7$ & $328 \pm 4$ \\
\hline Osmolality (mOsm kg ${ }^{-1} \mathrm{H}_{2} \mathrm{O} \mathrm{kg}^{-1}$ fish) & $442 \pm 51$ & $519 \pm 51$ \\
\hline Protein $\left(\mathrm{mg} \mathrm{g}^{-1}\right)$ & $16.3 \pm 4.1$ & $14.6 \pm 2.7$ \\
\hline Total lipid $\left(\mathrm{mg} \mathrm{g}^{-1}\right)$ & $16.4 \pm 7.9$ & $18.2 \pm 7.5$ \\
\hline Phospholipids (mg L ${ }^{-1}$ lipid) & $982 \pm 475$ & $1016 \pm 393$ \\
\hline Phospholipids (mg L $\mathrm{L}^{-1}$ bile) & $0.22 \pm 0.07^{\mathrm{a}}$ & $0.28 \pm 0.07^{\mathrm{b}}$ \\
\hline
\end{tabular}

1) TC, taurocholate; TCDC, taurochenodeoxycholate. 
Table 7. Triacylglycerol hydrolase (TAGH), sterol ester hydrolase (SEH) and wax ester hydrolase (WEH) activities in desalted luminal extracts from the midgut of Atlantic salmon fed either the control or Calanus diets. Means \pm S.D of 3 replicates, each with 3 individuals. Values with different superscript letter are significantly different $(P<0.05)$ as determined by nested ANOVA followed by the Tukey post hoc test.

\begin{tabular}{lcc}
\hline & \multicolumn{2}{c}{ Activity $\left(\right.$ pmol oleic acid $\min ^{-1}$ mg protein } \\
\cline { 2 - 3 } & Control diet & Calanus diet $^{-1}$ \\
\hline TAGH & $2610 \pm 1062$ & $3258 \pm 742$ \\
WEH & $891 \pm 243^{\mathrm{a}}$ & $1302 \pm 271^{\mathrm{b}}$ \\
SEH & $135 \pm 88^{\mathrm{a}}$ & $449 \pm 207^{\mathrm{b}}$ \\
\hline
\end{tabular}


